\title{
EPS8 wt Allele
}

National Cancer Institute

\section{Source}

National Cancer Institute. EPS8 wt Allele. NCI Thesaurus. Code C52518.

Human EPS8 wild-type allele is located in the vicinity of $12 q 13$ and is approximately $169 \mathrm{~kb}$ in length. This allele, which encodes epidermal growth factor receptor kinase substrate 8 protein, is involved in the mediation of the epidermal growth factor receptor signaling pathway. 